$p$-ISSN 1693-9484, $e$-ISSN : 2621-8313

Majalah Ilmiah Bahari Jogja (MIBJ)

Vol. 17 No. 2, Juli $2019 \quad$ (41-50)

DOI : $10.33489 /$ mibj.v17i2.208

(C) 2019 Akademi Maritim Yogyakarta

\title{
Perencanaan Dan Pengendalian Anggaran Operasi (Studi Pada PT Berlian Laju Tanker Tbk. Tahun 2006-2017)
}

\author{
Handoyo Widianto ${ }^{1 *}$, Iswanto ${ }^{1}$ \\ ${ }^{1}$ Ketalaksanaan Pelayaran Niaga, Akademi Maritim Yogyakarta, Jl. Magelang KM 4.4, \\ Yogyakarta 55284, Indonesia \\ * Corresponding Author. Email: handoyowidyanto28@ gmail.com. Hp 085800435419
}

\begin{abstract}
Abstrak
Penelitian ini meneliti pengendalian biaya operasi pada PT Berlian Laju Tanker Tbk. periode 2006-2017. Adapun masalah yang diteliti adalah apakah anggaran biaya operasional berperan dalam menunjang efektivitas pengendalian biaya operasional di PT Berlian Laju Tanker tahun 2006-2017. Penelitian ini merupakan penelitian deskriptif kuantitatif. Data yang diteliti dalam penelitian ini berupa data sekunder. Teknik pengumpulan data yang digunakan adalah metode dokumentasi dengan metode analisis deskriptif kuantitatif. Penelitian menemukan bahwa anggaran biaya operasional tidak berperan dalam menunjang efektivitas pengendalian biaya operasional di PT Berlian Laju Tanker tahun 2006-2017 (hipotesis tidak terbukti). Penyebab tidak berperannya anggaran biaya operasional dalam menunjang efektivitas pengendalian biaya operasional di PT Berlian Laju Tanker tahun 2006-2017 disebabkan anggaran yang ditetapkan perusahaan memang lebih rendah dari kebutuhan yang sebenarnya. Hal ini disebabkan perusahaan berusaha menghindari biaya-biaya yang tinggi, sehingga jumlah yang dianggarkan tidak sesuai dengan kebutuhan. Padahal anggaran tersebut sangat dibutuhkan, sehingga akhirnya perusahaan terpaksa tetap mengeluarkan biaya tersebut. Hal inilah yang menimbulkan terjadinya penyimpangan realisasi dari anggaran operasi.
\end{abstract}

\section{Kata Kunci: Anggaran Operasi, Perencanaan dan Pengendalian}

\begin{abstract}
This research covers operating cost at PT Berlian Laju Tanker Tbk. the period 2006-2017. The problem being studied is operational cost control at PT Berlian Laju Tanker year 2006-2017. This research is quantitative descriptive. The data studied in this research is secondary data. The technique used is the method of documentation with quantitative descriptive analysis method. The study found that operational budget can not control operational budget effectively in PT Berlian Laju Tanker at 2006-2017 (unproved hypothesis). Because planned operational is not match with realization operational which is actual cost lower than actual requirement. This because the company try to cut the high costs, so the amount budgeted does not fit the needs. Indispensable, the company needs the costs. This is what causes the deviation of the realization of the operating budget.
\end{abstract}

Keywords: Operation Budget, Planning and Controlling 


\section{PENDAHULUAN}

Setiap usaha yang dilakukan, bertujuan untuk memaksimumkan laba dengan biaya yang sekecil-kecilnya. Laba diperoleh dari pendapatan dikurangi biaya-biaya operasi, produksi, maupun biaya-biaya lainnya. Terkait dengan itu, untuk memaksimalkan laba, perusahaan perlu menyusun rencana anggaran untuk waktu yang akan datang berdasarkan data anggaran sebelumnya. Rencana anggaran itu disesuaikan dengan kondisi di masa mendatang dengan tujuan agar anggaran yang disusun dapat sesuai dengan kebutuhan anggaran di masa yang akan datang dan dapat meminimalisasi penyimpangan yang mungkin terjadi.

Peran anggaran sebagai alat perencanaan dan pengawasan merupakan satu kesatuan yang tidak dapat dipisahkan, karena perencanaan tanpa adanya pengawasan merupakan pekerjaan yang sia-sia karena sebaik apapun perencanaan yang dibuat tidak akan mungkin terealisasi dengan sesuai sasaran tanpa adanya pengawasan yang baik. Salah satu pengendalian yang dilakukan perusahaan adalah pengendalian biaya operasional. Biaya operasional merupakan keseluruhan biaya sehubungan dengan operasional perusahaan untuk membantu kelancaran operasi perusahaan.

PT Berlian Laju Tanker Tbk. adalah salah satu perusahaan yang bergerak di bidang jasa perhubungan laut yang menyelenggarakan jasa angkutan muatan cair dan gas. Untuk menjalankan segala kegiatan usaha tersebut dibutuhkan dana operasional. Dalam hal ini kebutuhan dana operasional dituangkan di dalam suatu perencanaan yang dinamakan anggaran operasional. Anggaran operasional merupakan anggaran yang digunakan dalam membiayai seluruh kegiatan usaha perusahaan.

Anggaran suatu perusahaan merupakan salah satu aspek penting dalam merencanakan keputusan yang akan diambil oleh manajemen suatu perusahaan. Apabila terjadi kekeliruan atau ketidaktepatan dalam merencanakan atau melaksanakan anggaran dapat berakibat buruk bagi perusahaan. Dalam hal ini, adanya anggaran perusahaan dapat menjadi pedoman bagi pihak yang terkait dalam perusahaan sekaligus dapat digunakan sebagai tolok ukur terhadap penyimpanganpenyimpangan yang seringkali terjadi dalam perusahaan. Apabila anggaran difungsikan dengan benar diharapkan akan semakin meningkatkan laba perusahaan.

Salah satu jenis anggaran perusahaan adalah anggaran operasi. Anggaran operasi merupakan batas pengeluaran biaya operasi yang dapat dilakukan oleh pusat pertanggungjawaban yang bersangkutan. Anggaran ini dapat membantu perusahaan untuk meningkatkan efisiensi dan efektivitas penggunaan sumber daya yang dimiliki oleh perusahaan.

Dengan adanya perencanaan anggaran biaya operasi diharapkan perusahaan dapat melaksanakan kegiatan yang telah direncanakan sesuai dengan apa yang telah dianggarkan oleh perusahaan, sehingga tidak terjadi penyelewenganpenyelewengan terhadap anggaran biaya operasi. Pengendalian biaya operasi yang didukung oleh controller, membantu manajer perusahaan untuk menganalisis, melakukan penilaian, merekomendasi serta memberikan informasi-informasi yang berkaitan dengan kegiatan operasi sehingga kemungkinan penyimpangan yang terjadi dapat ditekan seminimal mungkin serta dapat membantu mencapai tujuan perusahaan, yaitu untuk mencapai efisiensi dan efektivitas terhadap biaya operasi.

Majalah Ilmiah Bahari Jogja 42 | http://jurnal.amy.ac.id/index.php/MIBJ/ 
PT Berlian Laju Tanker merupakan perusahaan pengangkutan berskala internasional yang mengangkut muatan cair dan gas. Untuk mengendalikan anggaran pelaksanaan pengangkutan, PT Berlian Laju Tanker membuat anggaran operasi. Akan tetapi sebagai perusahaan yang tidak lepas dari faktor eksternal, maka beberapa kali perusahaan mengalami keadaan bahwa biaya operasi yang dikeluarkan ternyata lebih besar daripada biaya yang dianggarkan. Hal ini disebabkan adanya perubahan-perubahan biaya di perjalanan tahun anggaran. Kenaikan kurs valuta asing, kenaikan upah biaya tenaga kerja, kenaikan harga harga BBM, merupakan penyebab-penyebab yang selama ini sering menyebabkan anggaran perusahaan melebihi dari yang direncanakan. Ketika terjadi keadaan yang demikian, pihak Manajer Anggaran, Manajer Keuangan dan Manajer Akuntansi segera melaporkan keadaan yang ada kepada Direktur Utama.

Berdasarkan latar belakang masalah di atas dirumuskan masalah sebagai berikut: Apakah anggaran biaya operasional berperan dalam menunjang efektivitas pengendalian biaya operasional di PT Berlian Laju Tanker tahun 2006-2017?

\section{A. Pengertian Anggaran}

Anthony dan Govindarajan (1998) mendefinisikan anggaran sebagai sebuah rencana keuangan, biasanya mencakup periode satu tahun dan merupakan alat untuk perencanaan jangka pendek dan pengendalian dalam organisasi. Asri dan Adissaputro (2003) mendefinisikan anggaran sebagai suatu pendekatan yang formal dan sistematis dari pelaksanaan tanggung jawab manajemen di dalam perencanaan, pengkoordinasian, dan pengawasan. Sementara menurut Polinemi, 1986 (dalam Sinarasri, dkk., 2001) anggaran adalah suatu gambaran kuantitatif dari tujuan-tujuan manajemen dan sebagai alat untuk menentukan kemajuan dalam pencapaian tujuan.

Berdasarkan pendapat para ahli di atas, secara umum dapat disimpulkan bahwa anggaran adalah rencana tertulis yang tersusun secara sistematis dan terperinci dalam bentuk angka-angka dalam ukuran uang (satuan kuantitatif) dimana perusahaan menggunakannya sebagai pedoman dalam pelaksanaan kegiatan pada periode yang akan datang dan merupakan dasar untuk pengawasan. Dalam anggaran juga terdapat tindakan antisipasi untuk menyesuaikan keadaan di masa yang akan datang dengan rencana yang telah ditetapkan, karena itu anggaran juga dipakai sebagai alat koordinasi dan implementasi rencana awal dengan aktivitas yang sedang berlangsung.

\section{B. Manfaat dan Keterbatasan Anggaran}

Menurut Hansen dan Mowen (1997) manfaat anggaran bagi organisasi, yaitu:

1. Memaksa manajer untuk membuat rencana masa depan dan memotivasi manajer untuk mengembangkan arah bagi organisasi meramalkan kesulitan dan mengembangkan kebijakan masa depan.

2. Memberikan informasi sumber daya yang dapat meningkatkan kualitas pengambilan keputusan.

3. Sebagai standar bagi evaluasi kinerja yang memberikan dasar bagi penggunaan sumberdaya perusahaan dan memotivasi karyawan.

4. Dapat digunakan sebagai sarana komunikasi dan koordinasi yang secara formal mengkomunikasikan rencana organisasi kepada setiap karyawan. 
Menurut Nafarin (2000) manfaat anggaran adalah sebagai berikut:

1. Segala kegiatan dapat terarah pada pencapaian tujuan bersama.

2. Dapat digunakan sebagai alat menilai kelebihan dan kekurangan pegawai.

3. Dapat memotivasi pegawai.

4. Menimbulkan tanggung jawab tertentu pada pegawai.

5. Menghindari pemborosan dan pembayaran yang kurang perlu.

6. Sumber daya, seperti tenaga kerja, peralatan dan dana dapat dimanfaatkan seefisien mungkin.

7. Alat pendidikan bagi para manajer.

8. Program anggaran yang bagaimanapun bentuknya akan bermanfaat bagi setiap perusahaan.

Berkaitan dengan uraian di atas, manfaat anggaran dapat dikategorikan menjadi tiga, yaitu:

1. Anggaran sebagai alat penaksir

Dalam tahap ini aspek perencanaan sangat menonjol, sedangkan aspek pengendalian kurang berperan, di sini anggaran hanya berperan sebagai penentu arah.

2. Anggaran sebagai plafon

Dalam tahap ini ditekankan pada adanya evaluasi antara rencana dan realisasi sehingga yang menonjol adalah aspek pengendaliannya.

3. Anggaran sebagai otorisasi

Dalam tahap ini biaya lebih dikaitkan dengan jumlah biaya secara total bukan per pos sehingga dimungkinkan adanya pengalihan biaya total antar pos selama plafon biaya total belum terlampaui.

Di samping memiliki manfaat-manfaat sebagaimana dikemukakan di atas, anggaran juga mempunyai beberapa keterbatasan. Simamora, 1999 (dalam Nurhayati, 2005) menyatakan bahwa ada enam keterbatasan anggaran, antara lain:

1. Dalam banyak kejadian cenderung terlalu menyederhanakan fakta dari situasi di lapangan dan tidak secara konsisten menunjukkan kompleksitas yang dihadapi oleh manajemen.

2. Anggaran bisa saja terlampau menekan hasil-hasil (yaitu laba bersih sesungguhnya dibandingkan dengan jumlah laba yang dianggarkan) namun bukan pada sebab-sebabnya (yaitu penjelasan-penjelasan mengapa biaya pemasaran lebih tinggi dari yang dianggarkan).

3. Apabila para manajer tidak begitu yakin akan manfaat-manfaat anggaran, tipis kemungkinannya mereka akan mencurahkan waktu untuk menggunakannya secara sukses.

4. Anggaran dapat menggerogoti inisiatif manajemen dengan menghalangi perkembangan-perkembangan dan langkah-langkah baru yang tidak tercakup dalam anggaran.

5. Jika diberlakukan tekanan berlebihan terhadap manajer, maka manajer dapat bereaksi dengan keputusan yang berpengaruh buruk terhadap tujuan organisasional.

6. Proses penganggaran bukanlah ilmu murni dan pertimbangan yang baik memainkan peran esensial (agak subyektif). Dibutuhkan revisi konstan manakala ada fakta-fakta baru. 
Christina, dkk. (2001) menyatakan keterbatasan anggaran terdiri dari:

1. Penaksiran yang dipakai belum tentu sesuai dengan keadaan yang sebenarnya.

2. Keadaan yang digunakan sebagai dasar penyusunan anggaran mengalami perkembangan yang jauh berbeda dari yang direncanakan.

3. Penyusunan anggaran yang melibatkan banyak pihak, berpotensi menimbulkan persoalan hubungan kerja yang dapat menghambat proses pelaksanaan anggaran.

4. Tidak dapat terlepas dari penilaian subjektif pembuatan kebijakan, terutama saat data dan informasi tidak lengkap.

\section{Proses Penyusunan Anggaran}

Penyusunan anggaran dilaksanakan oleh Komite Anggaran yang anggotanya terdiri dari para manajer pelaksana fungsi-fungsi pokok perusahaan. Adapun proses penyusunan anggaran menurut R.A Supriyono (2001) adalah sebagai berikut:

1. Menganalisis informasi masa lalu dan lingkungan luar yang diantisipasikan dengan SWOT (Strength/kekuatan, Weak-ness/kelemahan, Opportunity/peluang, Threath/ancaman).

2. Menentukan strategi untuk mencapai tujuan organisasi dan strategi untuk mencapai tujuan tersebut.

3. Mengkomunikasikan tujuan organisasi, strategi pokok dan program

4. Memilih taktik, mengkoordinasi, dan mengawasi kegiatan yang akan digunakan untuk mencapai tujuan

5. Membuat usulan anggaran

6. Menyerahkan revisi usulan anggaran

7. Menyetujui revisi usulan anggaran dan mengesahkannya se-bagai anggaran perusahaan

8. Revisi dan pengesahan anggaran perusahaan

\section{Pengendalian Anggaran}

Menurut Usry dan Hammer (1997) pengendalian merupakan usaha sistematis perusahaan untuk mencapai tujuan dengan cara membandingkan prestasi kerja dengan rencana dan membuat tindakan yang tepat untuk mengoreksi perbedaan yang penting. Menurut Supriyono (1994) definisi pengendalian yaitu proses untuk menjamin bahwa pelaksanaan kerja yang efisien akan dapat mencapai tujuan perusahaan yang telah ditetapkan. Pengendalian digunakan untuk menjamin pencapaian tujuan-tujuan, sasaran-sasaran, kebijakankebijakan dan standar-standar secara efisiensi seperti yang telah ditentukan dalam perencanaan.

Dari pendapat para ahli di atas, dapat disimpulkan bahwa pengendalian adalah fungsi manajemen yang mengusahakan agar kegiatan terlaksana sesuai dengan rencana, instruksi, pedoman, patokan, pengaturan atau hasil yang telah ditetapkan sebelumnya, untuk kemudian dapat diambil tindakan perbaikan.

Dikaitkan dengan anggaran, maka pengendalian anggaran dapat didefinisikan sebagai seluruh kegiatan perusahaan, yang dinyatakan dalam unit (kesatuan) moneter dan berlaku untuk jangka waktu tertentu yang akan datang agar kegiatan terlaksana sesuai dengan rencana, instruksi, pedoman, patokan, pengaturan atau hasil yang telah ditetapkan sebelumnya, untuk kemudian dapat diambil tindakan perbaikan (Munandar, 2000). 


\section{METODE PENELITIAN}

Jenis penelitian ini adalah penelitian analisis deskriptif yang mencoba untuk menggambarkan obyek-obyek serta fakta-fakta yang terdapat di lapangan dengan jalan melakukan perbandingan antara obyek-obyek penelitian yang kemudian dari hasil-hasilnya dideskripsikan ke dalam suatu bentuk penjabaran (Indriantoro dan Supomo, 1999).

Dalam penelitian ini penulis menggunakan sumber data sekunder yang diperoleh dari situs Bursa Efek Indonesia. Teknik analisis data yang digunakan adalah analisis deskriptif, yaitu dengan menguraikan proses penyusunan anggaran operasional satuan kerja perusahaan dan proses pengendaliannya untuk kemudian dapat diketahui jawaban dari permasalahan yang telah dirumuskan.

Dari analisis ini akan ditemukan dua keadaan, yaitu keadaan biaya menguntungkan (favorable) dan keadaan merugikan (unfavorable). Keadaan favorable terjadi jika biaya anggaran lebih besar dari realisasi. Sedangkan keadaan unfavorable terjadi jika biaya anggaran lebih kecil dari realisasi. Pengolahan data dalam menganalisis anggaran tersebut menggunakan alat bantu yaitu berupa software komputer Microsoft Excel 2007.

\section{HASIL DAN PEMBAHASAN}

\section{A. Gambaran Umum Perusahaan}

PT Berlian Laju Tanker Tbk didirikan pada tanggal 12 Maret 1981 dengan nama PT Bhaita Laju Tanker dan mulai beroperasi secara komersial pada tahun 1981. Pada tahun 1988, perusahaan berganti nama menjadi PT Berlian Laju Tanker.

BLTA bergerak dalam bidang jasa menyediakan jasa transportasi laut dengan fokus pada pengangkutan muatan cair seperti pelayaran/angkutan laut baik dalam kawasan Indonesia maupun Asia, Eropa dan Amerika. Perseroan mulai beroperasi dengan dua tanker berukuran bobot mati 12.050 DWT.

Pada tahun 1990, Perseroan menjadi perusahaan pelayaran Indonesia pertama yang mencatatkan sahamnya di Bursa Efek Indonesia. Hal itu terjadi pada tanggal 22 Januari 1990. Saham-saham perusahaan dicatatkan pada Bursa Efek Indonesia (BEI) pada tanggal 26 Maret 1990. Sejak saat itu perusahaan terbuka dengan modal dari pihak luar dalam bentuk saham-saham yang ditawarkan ke bursa efek.

Dengan semboyan 'Mengangkut dengan Selamat, Kompetitif dan Tepat Waktu', Perseroan memiliki komitmen untuk memberikan pelayanan terbaik pada semua pelanggan. Komitmen ini ditunjukkan dengan kepatuhan pada International Safety Management Code, standar ISO 9001:2000, standar ISO 14001:2004 dan standar OHSAS 18001:1999, di mana Perseroan telah memperoleh sertifikat dari lembaga-lembaga internasional. Komitmen Perseroan untuk memberikan pelayanan terbaik dan mematuhi standar tertinggi diyakini akan dapat menjamin kelangsungan bisnis perseroan (Annual Report BLTA, 2006, 2007, 2008, 2009, 2010, 2011, 2012, 2013, 2014, 2015, 2016).

\section{B. Analisis Biaya Operasi}

1. Analisis Biaya Standar 
Dalam akuntansi biaya, akrab dengan istilah sistem biaya standar. Sistem biaya standar mencatat biaya yang seharusnya dikeluarkan dan biaya yang sesungguhnya terjadi, dan menyajikan perbandingan antara biaya standar dan biaya sesungguhnya serta menyajikan analisa penyimpangan biaya sesungguhnya dari biaya standar.

Melalui analisis ini pimpinan dapat segera mengetahui dimana terjadi pemborosan biaya dan berapa besarnya, serta dapat mengambil tindakan perbaikan untuk pelaksanaan periode yang akan datang. Dengan adanya analisa pelaporan penyimpangan memungkinkan pimpinan melakukan pengawasan terhadap prinsip pengecualian (managemeny by execption) yaitu pemusatan perhatian kepada halhal yang menyimpang dibanding standar yang telah ditetapkan. Ini berarti pimpinan memiliki alat efektif untuk mengawasi biaya.

Selain biaya standar, yang perlu dianalisis adalah biaya operasi. Analisis biaya operasi sangat penting dilakukan pada perusahaan yang bergerak di bidang jasa seperti PT Berlian Laju Tanker, karena tanpa biaya ini perusahan tidak akan dapat melaksanakan operasinya sedangkan operasi itu sendiri sangat penting untuk mendapatkan keuntungan perusahaan.

Terkait dengan perencanaan dan pengendalian anggaran, biaya standar dan anggaran merupakan dua hal yang sangat penting. Biaya standar digunakan untuk menentukan biaya per unit, sedangkan anggaran digunakan untuk menentukan seluruh belanja yang akan terjadi selama satu periode tertentu.

Berdasarkan uraian tersebut di atas dapat disimpulkan bahwa biaya standar merupakan dasar dalam penyusunan anggaran dimana standar menyatakan "yang seharusnya", bila pelaksanaan tertentu tercapai sedangkan anggaran merupakan "yang diharapkan" pada volume kegiatan tertentu dan bila keduanya dipakai bersama-sama, maka anggaran merupakan ikhtisar dari biaya-biaya standar.

\section{Analisis Varians}

Salah satu perhitungan yang dilakukan untuk mengetahui selisih anggaran yang direncanakan dan direalisasikan adalah analisis varians. Witjaksono (2013) menyatakan varians atau selisih adalah perbedaan antara suatu rencana atau target dan suatu hasil. Varians memberikan indikasi atau suatu peringatan bahwa operasi tidak berjalan sebagaimana yang direncanakan.

Analisis varians mencakup analisis matematis dari dua perangkat data untuk mendapatkan pendalaman penyebab terjadinya suatu penyimpangan atau varians. Salah satu jumlah diperlukan sebagai dasar standar atau titik pedoman. Sejalan dengan Witjaksono (2013), Mahmudi (2013) menjelaskan bahwa analisis varians dilakukan dengan cara mengevaluasi selisih terjadi antara anggaran dengan realisasi.

3. Analisis Varians Usaha Perusahaan Tahun 2006-2017

Tabel 1. Rangkuman Selisih Anggaran dan Realisasi Biaya Operasional

Tahun 2006-2017

\begin{tabular}{|c|l|c|}
\hline No & \multicolumn{1}{|c|}{ Aspek } & $\begin{array}{c}\text { Rata-rata Selisih } \\
(\%)\end{array}$ \\
\hline 1 & Gaji & 16,50 \\
\hline 2 & Perbaikan dan pemeliharaan & 19,83 \\
\hline 3 & Suku cadang & 21,00 \\
\hline
\end{tabular}

Majalah Ilmiah Bahari Jogja 47 | http://jurnal.amy.ac.id/index.php/MIBJ/ 


\begin{tabular}{|c|l|c|}
\hline 4 & Biaya pelumas & 10,67 \\
\hline 5 & Asuransi & 6,13 \\
\hline 6 & Transportasi & 15,25 \\
\hline 7 & Pengurusan dokumen & 15,00 \\
\hline 8 & Perlengkapan/bahan lain & 17,58 \\
\hline 9 & Uang makan & 17,00 \\
\hline 10 & Manajemen & 13,83 \\
\hline 11 & Beban docking & 16,50 \\
\hline 12 & Lain-lain & 8,67 \\
\hline
\end{tabular}

Dari rata-rata penyimpangan realisasi dari anggaran operasi yang disajikan dalam Tabel 1, diketahui urutan penyimpangan yang terjadi adalah Suku Cadang (21\%), disusul Perbaikan dan Pemeliharaan (19,83\%), Perlengkapan/Bahan Lain $(17,58 \%)$, Uang Makan (17\%), Gaji (16,50\%), Transportasi (15,25\%), Pengurusan Dokumen (15\%), Manajemen (13,83\%), Biaya pelumas (10,67\%), Beban Docking $(8,67 \%)$, dan Asuransi $(6,13 \%)$. Berdasarkan urutan tersebut, diketahui penyimpangan tertinggi terjadi pada 3 aspek, yaitu Suku Cadang, disusul Perbaikan dan Pemeliharaan, Perlengkapan/Bahan Lain.

Penyimpangan anggaran tertinggi terjadi pada suku cadang, disebabkan kapal-kapal perusahaan ada yang sudah berumur tua. Sebagaimana diketahui per tanggal 31 Desember 2006, umur rata-rata kapal tanker Perseroan pengangkut bahan kimia, minyak dan gas masing-masing adalah 8,$4 ; 14,1$ dan 11,9 tahun. Jika pada tahun 2006 umur kapal adalah setua itu, maka pada tahun 2017 umurnya adalah 19,4; 25,1 dan 22,9 tahun (dari 2006 ke 2017 adalah 11 tahun). Umur seperti ini sudah cukup tua, sehingga wajar membutuhkan penggantian suku cadang. Di lain pihak, suku cadang kapal besar seperti yang dioperasikan perusahaan, harganya mahal-mahal. Oleh karena itu, sangat wajar jika biaya ini mempunyai penyimpangan yang besar, karena jika pembelian suku cadang belum dianggarkan tetapi karena keadaan terpaksa harus dibeli, maka perusahaan harus mengeluarkan biaya di luar anggaran yang cukup besar.

Penyimpangan tertinggi berikutnya terjadi pada anggaran perbaikan dan pemeliharaan. Sebagaimana uraian di atas, dengan kondisi umur kapal yang sudah tua-tua, maka anggaran perbaikan dan pemeliharaan otomatis meningkat sejalan dengan umur kapal. Selain itu, bagi perusahaan sepanjang pembelian suku cadang masih bisa ditunda dengan usaha perbaikan dan pemeliharaan saja, maka hal itulah yang dilakukan, mengingat harga suku cadang kapal sangat mahal.

Anggaran lainnya yang mengalami penyimpangan tertinggi adalah anggaran perlengkapan/bahan lain. Anggaran ini menjadi tinggi karena untuk mengoperasikan kapal banyak sekali hal-hal yang perlu dilengkapi. Kapal harus dilengkapi dengan peralatan-peralatan yang bisa digunakan kapal dalam keadaan darurat. Apalagi mengingat muatan kapal adalah barang-barang yang mempunyai risiko tinggi dan juga nilai yang tinggi, seperti kimia cair (organik dan anorganik), gas cair (LPG, gas kimia, propylene, propane, LNG dan dan gas-gas bertekanan lainnya), produk minyak (minyak mentah, kerosene, solar, bensin), pelumas (pelumas dasar dan aditif), serta minyak nabati dan hewani. 
Tidak efektifnya anggaran operasi PT Berlian Laju Tanker dalam pengendalian biaya operasional, disebabkan anggaran yang ditetapkan lebih rendah dari biaya sesungguhnya yang dibutuhkan perusahaan, sehingga jumlah yang dianggarkan tidak sesuai dengan kebutuhan. Padahal anggaran tersebut sangat dibutuhkan, sehingga akhirnya perusahaan terpaksa tetap mengeluarkan biaya tersebut. Hal inilah yang menimbulkan terjadinya penyimpangan realisasi dari anggaran operasi.

Penyebab perusahaan menetapkan biaya operasi lebih rendah dari kebutuhan sebenarnya dikarenakan keadaan keuangan perusahaan sejak tahun 2006 mengalami penurunan (kerugian terus-menerus), sehingga perusahaan tidak mampu memenuhi kebutuhan biaya operasinya. Buruknya pendapatan perusahaan terlihat pada tahun 2012, PT Berlian Laju Tanker telah gagal bayar atas beberapa kreditur utang usaha terkait dengan perbaikan dan pemeliharaan kapal dan pembelian bahan bakar. Utang-utang ini direklasifikasi ke dalam utang lain-lain sementara PT Berlian Laju Tanker sedang dalam negosiasi dengan para kreditur.

\section{SIMPULAN}

\section{Kesimpulan}

Berdasarkan penelitian dan pembahasan yang dilakukan dapat disimpulkan bahwa anggaran biaya operasional tidak berperan dalam menunjang efektivitas pengendalian biaya operasional di PT Berlian Laju Tanker tahun 2006-2017 (hipotesis tidak terbukti). Hal ini terlihat dari keseluruhan anggaran operasional perusahaan mengalami kondisi unfavorable (tidak menguntungkan) yaitu realisasi anggaran lebih besar dibandingkan anggaran yang dibuat.

Penyebab tidak berperannya anggaran biaya operasional dalam menunjang efektivitas pengendalian biaya operasional di PT Berlian Laju Tanker tahun 20062017 disebabkan anggaran yang ditetapkan perusahaan lebih rendah dari kebutuhan yang sebenarnya. Hal ini disebabkan perusahaan berusaha menghindari biaya-biaya yang tinggi, sehingga jumlah yang dianggarkan tidak sesuai dengan kebutuhan. Padahal anggaran tersebut sangat dibutuhkan, sehingga akhirnya perusahaan terpaksa tetap mengeluarkan biaya tersebut. Hal inilah yang menimbulkan terjadinya penyimpangan realisasi dari anggaran operasi.

\section{Saran}

Berdasarkan pembahasan yang dihasilkan dapat diberikan saran-saran sebagai berikut:

1. Perusahaan disarankan untuk membuat rencana anggaran yang akan datang sesuai dengan biaya yang sesunguhnya, sehingga anggaran biaya operasional benar-benar dapat berperan dalam menunjang efektivitas pengendalian biaya operasional perusahaan.

2. Perusahaan disarankan untuk melakukan penyesuaian anggaran yang direncanakan dengan realisasinya, sehingga dalam perjalanan tahun anggaran, kesenjangan antara anggaran dan realisasi bisa diperbaiki. 


\section{DAFTAR PUSTAKA}

Anthony, Robert N. dan Vijay Govindarajan, 2004, Manajemen Control System, New York: Mc. Grawhill.

Asri, Marwan dan Gunawan Adisaputro, 1984, Anggaran Perusahaan, Edisi Revisi II, Yogyakarta: BPFE.

Christina, Ellen, M. Fuad, dan Edy Sugianto, 2001, Anggaran Perusahaan, Suatu Pendekatan Praktis, Jakarta: PT. Gramedia.

Hansen dan Mowen, 1997, Akuntansi Manajemen, Edisi Keempat, San Diego: South Western College Publishing.

Indriantoro, Nur dan Bambang Supomo, 1999, Metodologi Penelitian Bisnis Untuk Akuntansi dan Manajemen, Edisi Pertama, Yogyakarta: BPFE.

Mahmudi, 2013, Manajemen Keuangan Daerah, Jakarta: Erlangga.

Munandar, M., 2000, Budget, Perencanaan Kerja, Pengkoordinasian Kerja, Pengawasan Kerja, Yogyakarta: BPFE.

Nafarin, M., 2000, Penganggaran Perusahaan, Edisi Pertama, Jakarta: Salemba Empat.

Sinarasri, Andiwiani, dkk., 2001, "Hubungan Manusia dan Sistem Penganggaran". Jurnal Bisnis dan Akuntansi, Volume 3, Nomor 3, Desember 2001.

Supriyono, R.A. 1994, Anggaran Perusahaan, Perencanaan dan Pengendalian Laba, Yogyakarta: SYIE YKPN.

Supriyono, R.A., 2001, Manajemen I; Konsep Dasar Akuntansi Manajemen dan Proses Perencanaan, Edisi Pertama, Yogyakarta: STIE YPKN.

Usry, Milton F. and Lawrence H. Hammer, 1997, Akuntansi Biaya, Perencanaan dan Pengendalian, Alih Bahasa Alfonsus Sirait dan Herman Wibowo, Surabaya: Erlangga.

Witjaksono, Armanto, 2013, Akuntansi Biaya, Edisi Revisi, Yogyakarta: Graha Ilmu.

Publikasi Bursa Efek Indonesia

Annual Report PT Berlian Laju Tanker, Tbk. 2006. Annual Report PT Berlian Laju Tanker, Tbk. 2007. Annual Report PT Berlian Laju Tanker, Tbk. 2008. Annual Report PT Berlian Laju Tanker, Tbk. 2009. Annual Report PT Berlian Laju Tanker, Tbk. 2010. Annual Report PT Berlian Laju Tanker, Tbk. 2011. Annual Report PT Berlian Laju Tanker, Tbk. 2012. Annual Report PT Berlian Laju Tanker, Tbk. 2013. Annual Report PT Berlian Laju Tanker, Tbk. 2014. Annual Report PT Berlian Laju Tanker, Tbk. 2015. Annual Report PT Berlian Laju Tanker, Tbk. 2016. 